\title{
Politics vs. Market; Implication of the Present Trade Row on US -Sino Relations and Global Balance of Power
}

\author{
Rashad Yazdanifard and Nnamdi Ogbodoakum.
}

\begin{abstract}
Trade disputes and potential broader conflicts between Washington and Beijing need to be averted due to high risk potentials it poses to the global economy. US leadership, influence and other capabilities largely depends on her strong economy. U.S competitive advantages in key industries are almost nonexistent now, as economic re balancing continues to take its toll on the overall economy; jobs that nurtured the most cherished ideal in modern history (AMERICAN DREAM) are in their droves to emerging countries with comparative advantages. Both the short to medium and long -term implications of a weakened American will be felt in its global Leadership, regional security, diplomacy and development. (Aims) the paper will explore the connection between China's currency value and US trade deficit with particular emphasis on the rise of protectionism against free market principle. The relationship between economic growth and power will be explained in other to understand the implication of rising China on Asian pacific and on emerging new global order. (Methods) we have reviewed available literatures on the subject matter in other to support the above objectives and the Results showed that, China's currency appreciation without adequate structural reforms in the US will have less than expected impact on the huge trade deficit; Protectionism will continue to gain momentum against free market as competitions intensify among the major economic players in protecting their prized assets. Moreover, rising China with its economic prowess could tilt the balance of power and possibly challenge American global Leadership and influence. Both the short to medium and long -term implications of a weakened American will be felt in its global Leadership, regional security, diplomacy and development.
\end{abstract}

Index Terms - International Relations, Protectionism, Rising China, U.S Trade deficit

\section{INTRODUCTION}

The year 2011 will go down in recent memory as the most complicated, tortuous and globally challenged year in recent history no thanks to series of events that happened within the first seven months. The year was greeted with sudden invent in Tunisia that spread across the Arab nations, notably: Egypt, Syria, Bahrain and Libya, the demonstration resulted in change of government in Egypt and Tunisia. Japan compounded its economic woes with the worst natural disaster in recent memory that claimed thousands of lives with long term severe economic consequences. In July 092011 a new nation was born, the Republic of South Sudan officially separated from Khartoum after many years

Manuscript received July 26, 2011; revised September 21, 2011.

Rashad Yazdanifard is with the Faculty of Management, Multimedia University, Cyberjaya, Malaysia. (rashadyazdanifard@yahoo.com).

Nnamdi Ogbodoakum is with the Center of Post Graduate Studies, LimkokwingUniversity of Creative Technology, Cyberjaya, Malaysia (nnamdiogbodoakum@yahoo.com). of civil war, with the control for oil expected to generate conflict if not properly managed. Furthermore, the master minder of 9/11 bombing in US, Osama bin laden was killed. The above invents happened without interrupting the global economic resetting with much needed long term geopolitical balance of power that will not only assume new and unpredictable dimension but will ultimately reset global pendulum of power, authority, and legitimacy. [17].

The rise of China to a global power within a short period has been adjudged by scholars, researchers and policy analysts as the greatest economic transformation in modern history. Who could think that China within three decades or so would be endowed with the following features and projections: China's economy is now, second to the United States with available estimates and projections pointing that China could topple the USA in no distant time.

This work was submitted for review on 22 July, 2011

From agrarian economy to a global production center, China is now the largest auto market beating the USA thanks to its emerging middle class. Beijing could influence the stability of dollars owing to its vast reserve holdings which at the time of writing this report are in excess of one trillion dollars. China could be comfortably addressed as a continent since one in every five people on earth lives in China or is a Chinese.

Beijing is now the largest exporter and fastest growing economy with the latest quarterly GDP to June 2011 of $9.5 \%$ slightly lower the 2011 first quarter of $9.7 \%$. The Euro zone is presently engulfed in a protracted debt crisis involving Greece and other potentially red flag like Spain and even Italy could challenge the relevance of European Union in the emerging order. Moreover, the gloomy outlook of the United States economy as shown by the latest unemployment figure of $9.2 \%$ as of June 2011 could even be worse if United States debt ceiling expiring on 2 August 2011 is not resolved by Washington Political leaders. The expected roles to be played by China in the emerging global order is been debated vigorously among researchers, scholars and diplomats. [16], [17].

U.S policy makers across the aisle must understand, that wining the future involves moving from a mere political and economic rhetoric of competitiveness to aggressive and concrete policies to address the structural impediments to growth and sustainability otherwise the looming economic precipice will not only have serious economic consequences, but will damage the already faltering American leadership and Diplomatic Prowess, debase the status of greenback as an effective international reserve. [17]. Both the short to medium and long term implications of a weakened American will be felt in its global Leadership, regional security, diplomacy and development.

The paper will highlight the potential implications of 
China's new international standing on balance of power, American leadership and emerging economic order. The effect of protectionism will be examined as countries try to protect their interests. Furthermore, the relationship between renmimbi appreciation (China Currency) and United States trade deficit will be explained, recommendations will be made for beneficial trade relations, which will be critical in 21 st century. We believe that at the end of the exercise, we might have contributed something that will assist concerned policymakers, diplomatic experts, commentators and opinion leaders in Beijing and Washington to continue the path of dialogue, mutual respect and effective communication in resolving some expected disputes and differences that will arise

\section{PRESSURE ON CHINA TO FlOAT RENMIMBI}

The 2008 global financial crisis changed the dynamics and relevance of some previously held concepts and norms about market economy, U.S global leadership which depends on market driven economic liberalism was seriously questioned. Washington global dominance in setting policies and best practices were severely challenged if not damaged, US moved from policy maker to policy negotiator. Beijing with its Authoritarian Capitalism saw itself assuming a new international profile with added clouts as demonstrated in stabilizing the international financial system from total collapse. Prior to 2008 financial crisis, American Consumers continue to drive economic growth around the world with their spending prowess which no other nation could match. The opposite was the case during the financial crisis; many countries that depended on U.S like China were severely affected. Beijing has realized that too much dependence on foreign consumption as a competitive strategy is unsustainable. [16] [17].

Exchange Rate: This is the price by which one currency can be exchanged with another currency in international transaction. A country's exchange rate reasonably determines the price of its goods and services in the international market. An undervalued currency has the potential of boasting export, especially an export driven economy like China. Until 1980s, economic reckoning played little or no interest in determining China's exchange rate policy. However, the situation changed considerably, when market reforms were introduced. China launched a dual exchange rate regime, where the official pegged rate supported the independent exchange rate centers. Furthermore, the communist government merged the official pegged system with the independent centers to create a managed floating system [6].

Opinion Leaders in United State are blaming the current policy of China towards its currency as the main reason for its high trade deficit according to them undervalued China's currency is an unwanted subsidy which undermines American competitiveness. The efficacy of renmimbi appreciation as a singular prescription to correct the US trade deficit is yet to be established. [1], [2] [15]. The trade imbalances between United State and China according to some experts stems from domestic policy differences and present cost structures in providing goods and services, which are in favor of China and starkly against the United
States. China's State controlled Capitalism, cannot be compared with American Market driven Economy. Also, the United State chronic trade deficit caused by debt fueled consumption contrasts sharply with the Chinese trade surplus, owing to its export induced strategy. [1], [15]. Bremmer.I, and Roubin, N. [4], argued that the position of the dollar as the reserve currency has placed United State in a serious policy conundrum, using Triffin dilemma, US must run a budget deficit in order to provide international liquidity, and the excessive deficit in honoring the obligation will undermine the dollars as a stable and effective international reserve.

Within the last quarter of 2010, the lower house of the United States Congress, the house of Representative passed a legislation labeling China a "Currency Manipulator" the bill authorized the concerned Government department to charge duties on imports from countries that are manipulating their currencies in order to gain undue advantages. [7], [13]. China believes that bowing to the external pressure on its currency policy will reduce its exports with corresponding high unemployment, social and economic unrest, which could undermine its domestic influence. [3]. Renmimbi appreciation may not necessarily improve the United State deteriorating export against China because of the followings:

Beijing is the biggest creditor to the Washington, as a result of the massive treasury bills she holds; U.S will have little leverage to influence the exchange rate much. [2]. U.S. manufacturers and service chains have a significant presence in China; any additional cost would be borne by the concerned enterprise or be passed to the already stretched U.S Populace. [2]. China will have little or no interest to cave into a policy, which could likely result in shifting jobs to countries with comparable cost advantages in South East Asia and Africa [10].

Washington will have to develop a winning strategy in managing intercontinental problems which will inevitably be dominated and or influenced by various countries and interests in years to come. Washington Power and influence over the years have been a strategic combination of its military capability, liberal orientation and economic might. U.S competitive advantages in key industries are almost nonexistent now, as economic re balancing continues to take its toll on the overall economy; jobs that nurtured the most cherished ideal in modern history (AMERICAN DREAM) are in their droves to emerging countries with comparative advantages. The innovative and creative policies which will ensure a favorable standing and competitiveness in 21 century have not been introduced due to partisan interest of politicians and lobbyists who values short-term electoral gain more than long-term prosperity. [17].

\section{RenMimbi ON THE Global StAGE}

China as a global power will undoubtedly alters the existing power equation Militarily, Economically, and Diplomatically. There is a growing resentment and profound suspicion that the new China poses a significant threat, no thanks to the recent skirmishes on the South China Sea with some of its neighbors. Beijing is fast using her new bolstered international image to forge series of mouth 
watering commercial interests that will guarantee constant supply of natural resources to feed its growing export industries.

Many Influential Chinese technocrats have suggested the use of IMF special drawing as the reserve currency against the dollar, a move that will be fiercely rejected by Washington since such an act not only will undermine the central role of the dollar as the reserve currency, but could be a serious threat to U.S global leadership [4]. Furthermore, the prospect of renmimbi replacing the dollar will require some tough decisions from Beijing, which includes, but are not restricted to a free exchange rate regime and not a managed type as it is now, liberalization of domestic capital market, free flow of capital, functioning and efficient renmimbi denominated debt. From available indications, China's compliance with the above structural changes will be difficult in near future. [4].

Brazil, Switzerland, Thailand, Vietnam recently instituted reasonable capital control measures in other to maintain price stability and to guard against the influx of hot money. [9]. Gandel. S. [11], suggested that in a crisis period, economic growth and inflation are mutually exclusive. Lowering the interest rate to achieve a modest growth will drive down the value of the currency and the excess demand of the cheap currency could result in influx of hot money, asset bubbles and inflation. On 16 October 2010, the "Economist" under an article captioned "how to stop a currency way" argued that instead of barrage of criticisms against China change its currency policy, Beijing may be appealed to increase her spending in other to correct the staggering trade imbalances [9]. The absence of welldeveloped and functioning spot and forward market together with fear of losing its monetary and currency policies will continue to enhance intervention proclivity from the Chinese authorities. [6], [8].

From Asia, African to Middle East down to Latin American, China is the new king in town, as its new spending powers continues to provide the much needed succor in various countries. Interpreting China's foreign policy in the emerging world order will be a herculean task that will confront not only the present and future US leaders, diplomats' and commentators, but Beijing's neighbors alike. The only consensus is that, the emerging China will alter the global balance power and may in no distant time uses its vast global economic web and growing military modernization to challenge America Leadership.

\section{OPEN MARKet SyStem OR PROTECTIONISM}

The direction of trade, investment and capital flow will continue to receive front-page headlines considering the shocking trade imbalances between developed countries and emerging ones. Political leaders, especially from the west are under increasing pressures to revive their economies and create the much needed jobs. Financial assets are increasingly coming under strong protection, political considerations and exigencies rather than sound economic judgments will continue to determine the size and flow of capital and investment in years to come. [4]. in 2005, an attempt by Chinese's state owned oil Company to acquire its US counterpart; UNOCAL received widespread commendations and attacks from Washington, furthermore, the planned stake ownership in American $3 \mathrm{COM}$ by Chinese Huawie was called off after security concerns were raised. Similarly, in 2006, Dubai World Ports was denied a planned acquisition of a company that would have allowed it, unfettered access, control and management of several ports in the United States.

The act of protectionism directly, through legislation, tariffs, quotas or indirectly, by bureaucracy and limitless definition and application of "ESSENTIAL INDUSTRY STATUS" will continue to be witnessed in the years ahead. [4], [12]. Takenaka. H. [14] emphasized that, in Asia's region, Bush-era policy of "TOO BIG TO FIAL" has been copied tenaciously. Japan recently re nationalized its postal service system after it was previously privatized; this was coming after its moribund airline was saved from an assured bankruptcy parkway, government in Seoul is establishing a fund to support its export related industries in order to boast their competitiveness. As authoritarian capitalism continues to evolve in the modern era, governments around the world will be churning out policies, procedures and regulations to protect their interests, key industries and markets. The penchant for chauvinistic nativism will be broadened and even elevated to a dangerous level

\section{EFFECT OF RENMIMBi APPRECIATION ON US TRADE BALANCE}

Economic stability will undoubtedly continue to influence policymakers in Beijing who have realized that precipitous appreciation of its currency will be counterproductive. Also, China's resolve to stimulate its economy will only be effective through domestic price stability; otherwise potential asset bubbles will have the unintended consequences. United State trade deficit with China in 2005 from available estimate was $\$ 201.5$ billion. Three years after Beijing introduced crawling peg exchange regime, which resulted in a substantial appreciation of its currency by at least $20 \%$, the trade deficit still rose to a surprising $\$ 266.3$ billion more than $30 \%$ from 2005 levels. The above scenario challenged the assumption that renmimbi appreciation may reduce the US trade deficit. [5], [13].

Chinese officials have consistently maintained that US economic quagmire is not an exchange rate issue, but on the United States Internal economic policies which needed fundamental reforms. Moreover, the astounding trade imbalance according to some Beijing officials may be related to productivity disparities between them. [8], [5]. Some commentators and business leaders are insisting that currency appreciation will have a significant influence on US trade balance, and the struggling export market. According to them, renmimbi appreciation will result in expensive imports from China with the corresponding export boast within the US, since export will be relatively competitive with a cheap dollar. However, some economists have countered that, appreciation will have less than an expected impact on US trade balance, export and job prospects. [13] [15].

\section{NEW ChINA IN THE EMERGING WORLD:}

Beijing ascendancy to a global giant will continue to be a 
huge surprise to many due to relative short period. A closer look and understanding of History will justify that Beijing has been dominating the world significantly except during the 18th century. China's greatest undoing was when the former Ming dynasty cut itself off from long maritime trade and the disregard for market reforms during Mao Zedong era. China had learned a lot from its neighbors in boasting its economic growth: Beijing understood the Japanese secret in value added export mindset through the acquisition of relevant technologies and strong government patronage. [18].

Communist China learned from South Korea how to transform a State owned enterprise into a world acclaimed leader in various industries, this concept is clearly visible because its economy is presently dominated by powerful, but profitable state owned entities in (banking, energy, telecoms, steel and mining). Beijing equally emulated Taiwan in using export processing zones to create competitive advantages and technological transfer. Finally Singaporean method of using EDI from MNCs as catalyst for growth, industrial capability and local content development was not left out. The apogee of the above development on china's current global standing is not acclaimed superior Chinese culture by the Communist leaders but, the open door policy of the west and sudden change in geopolitical economics occasioned, by globalization. [18].

Sino- American relationship and potential competition for power and influence may not only be a result of misconception or policies differences between the two nations, but a sudden rebalancing and changes in international system. Historically, the struggle between emerging powers and established ones has not been a bed of roses as the dominant and established powers normally regard themselves as the custodian of the international order, which is expected to guarantee their interests. The emerging ones by contrast, often hold the view that the status quo institutionalized by the dominant power are meant to defeat and probably constrained their ascendency and relevance. [19].

Washington and particularly Beijing's neighbors are of the opinion that rising China will pose significant challenge to their existence. As China capabilities continue to grow, the urge to expand and possibly dominate its immediate environment will be high. Beijing's desire to defend and protect core interest will increase the urge to reach beyond its borders for more markets, access to cheaper and readily available raw materials and reliable transportation routes. The relationship between wealth, power and geographical interest is a proved norm in geopolitical affairs. Sudden wealth encourages expansion which could result in insecurity and fear, and the urge for more power will be high to defend, protect and subdue the perceived fear, threat and insecurity. The potential for conflicts abound when the ascendant tries to challenge the existing international system, established rules, procedures and territorial boundaries. [19].

\section{DISCUSSION}

US trade balance with China will continue to be a hot topic among economists, Business Leaders and policymakers. From recent evidence, the impact of such appreciation on US trade balance with China is debatable and subject to various interpretations. From 2005 to 2008, as indicated before when Beijing introduced a crawling peg currency regime with a minimal appreciation, instead of the trade deficit to show expected reduction, it increased surprisingly. The only variable that may have influenced the above scenario will be high Consumption. Chinese currency appreciation without adequate and long-term economic reforms in the US may not have the much awaited impacts on exports and its attendant job creation. Since the Chinese State controlled capitalism differs with US Market driven economy, the ability of the communist regime to influence and possibly manipulates other economic factors is greatly enhanced. We are suggesting the followings for better trade deals and harmonious relations.

China should pursue a sustainable macroeconomic framework to improve its local consumption rather than so much reliance on export markets. This may not be palatable with many Chinese Leaders considering the huge implications on their export market; however, the negative effects of inflation and unnecessary exposure to foreign unpredictable conditions would be averted through a strong domestic consumption base.

Beijing should realize that recent astronomical economic numbers could be unsustainable, considering the prospects of strong economic outlook from emerging economies with comparable cost advantages; accordingly, strong local consumption base would be essential in mitigating unnecessary external shocks.

The majority of Chinese spend their money on basic foods notably Pork and cooking oil. From the latest inflation figures, price for pork increased substantially to $57 \%$ from last year figure. The (Consumer price Index) CPI increased by $6.4 \%$ from June last year and the overall food prices on CPI increased by about 14.4 from May 2011 figure. Beijing must be aware that its continued stability in near future will depend largely on economic stability and well-being of its people which inflation as indicated above is trying to challenge.

US policymakers should understand that the current economic quandary was not primarily caused by China's exchange rate policy, but a structural and deeply rooted economic ailment that demands result oriented over hauling, dully supported by strong and united political leadership as against the present partisan economic solution geared towards electoral gains. Export oriented drive against the existing and unsustainable debt induced consumption demands an immediate wide range reforms.

Appreciation of renmmbi without solid export boasting reforms will have less than the expected impact on its trade balance and highly politically charged job prospects. The urgency of the reform is equally re enforced by the fact that extra income earned by US corporations may not be spent completely in the US as globalization continue to force organizations to be competitive. Opinion Leaders need to recognize that US leadership, influence and other capabilities largely depends on its strong economy and Low-end job will be difficult to be retained and or created in US due to stark differences in cost structures with other emerging countries; hence, the reforms should be directed to 
developing other competitive industries.

\section{CONCLUSION}

US should demonstrate strong international leadership in leading the effort to integrate China into the existing order so that Beijing can contribute positively in tackling emerging global threats. The relations between US and China will be closely monitored in the 21 st not only in economic front, but on a wide range of issues.

Beijing should continue to exercise high degree of caution and sobriety in managing its new found powers and influence instead of overly aggressive policies and actions that could re enforce suspicion and resentment not only from the United States, but from its neighbors. The above italicized phrase will not only win more friends and solidify its international standing, but will direct more energy and available resources towards long-term growth, domestic stability of its local economy.

Mutual understanding, respect and cooperation rather than confrontation will be essential in avoiding potential conflicts, which may drastically affect the entire world.

\section{REFERENCES}

[1] Rajan. R. Currencies Aren't the Problem: Fix Domestic Policy, Not Exchange Rates. Foreign Affairs.2011, Mar/Apr, 90 (2) pp.104-116.

[2] Green.J. China's Changing Currency Policy: Something to Fear? Supply \$ Demand Chain Executive.2010, Nov/Dec.pp.22-23.

[3] Maich. S. America, China and a whole new kind of war: Canadian Business.2010, 83 (18) p.9.

[4] Bremmer.I, and Roubin, N. A G-Zero World, Foreign Affairs.2011, Mar/Apr, 90 (2) pp.2-7.

[5] Mckinnon. R.I. Perspective, China's Exchange Rate Policy and Fiscal Expansion. Journal of Chinese Economic and Foreign Trade Studies.2009, 2 (2) pp.81-85.

[6] Soofi. S.A. China's Exchange Rate Policy and the United States Trade Deficits. Journal of Economic Studies, 2009, 36(1) pp.36-65.

[7] The Monitor's Editorial's. Perils of clashes with China over currency and rare-earth exports. Christian Science Monitor. 2010, 29 September. Available through: Ebscohost database [Retrieved 23 March 2011].

[8] Xinzhen. L. Rise of the Yuan: Beijing Review.2008, January 24, 51(4) pp.30-31.

[9] How to stop a currency war. (Cover story). Economist. 2010 October 16, Available through: Ebscohost database [Retrieved 23 March 2011].

[10] Stewart. D. Yuan Revaluation Debate shows link between Economics and Politics. Policy Innovation.2007, [Online] Available at: http://www.policyinnovations.org/ideas/policy_library/data/01418/_re s/id=sa_File1/Asia\%20Society\%20A4_1.pdf [Retrieved 23 March 2011].

[11] Gandel. S. A Currency Race to the Bottom, Time. 2011, 177(2) p.4.

[12] How Far will it go? 2005. Economist, 376 (8436) pp.67-68, Available through: Ebscohost database [Retrieved 23 March 2011].

[13] Pento. M. US will lose a Trade and Currency War with China, Huffington Post, 2010 [Online] Available at: http://www.huffingtonpost.com/michael-pento/us-will-lose-a-tradeand_b_527523.html [Retrieved 17 March 2011].
[14] Takenaka. H. The Chinese Mirror Reflects, Khaleji Times, 2011 [Online] Available at: $<$ http://www.khaleejtimes.com/DisplayArticleNew.asp?section=opini on\&xfile=data/opinion/2011/march/opinion_march31.xml> [Retrieved 18 March 2011].

[15] Leonhardt. D. Baker vs. Scissors: A Debate on China, The New York Times, $2010 . \quad$ [Online] Available at:http://economix.blogs.nytimes.com/?s=Baker+vs. + Scissors\%3A+A +Debate+on+China [Accessed 18 March 2011].

[16] Lee. Y.J. A rising China and its Economic Implications, The Asia Foundation, 2010. [Online] Available at: http://asiafoundation.org/resources/pdfs/5.LEEJiyong.pdf [Accessed 18July 2011]

[17] Bremmer. I. On the Economy Be Careful What You Wish Others. Foreign Affairs, 2011, July/August [Online] Available at: http://www.foreignpolicy.com/articles/2011/06/20/on the economy be_careful_what_you_wish_for [Accessed 18July 2011]

[18] Friedman. E. Understanding China's Global impact. Diplomat, [Online] Available at: http://the-diplomat.com/whats-nextchina/understanding-china $\% \mathrm{E} 2 \% 80 \% 99$ s-global-impact/ [Accessed 18July 2011]

[19] Friedberg L. A. Hegemony with Chinese Characteristics, The national Interest, [Online] Available at: http://nationalinterest.org/article/hegemony-chinese-characteristics5439 [Accessed 18July 2011]

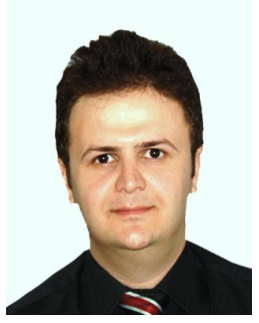

RASHAD YAZDANIFARD, (IRAN - 22/05/ 1982), Diploma in Mathematics and Physics, Allameh Tabatabaee, Tehran, Iran. B.B.A(Bachelor of Business Administration), Azerbaijan Accounting \& Management Higher education Institute, Iran. M.A. (Industrial Management), Shahid Beheshti University, Iran. He has done his Work completion seminar in his $\mathrm{PhD}$ in the field of Marketing at Multimedia University, Malaysia and he is currently in final stages of completing his Viva. His Major Field of Study is online marketing and E commerce.

He has been lecturing in several Universities since 4 years ago, and since 3 years ago till now, He has been lecturing in Limkokwing University of Creative Technology in Center Of Post Graduate Studies and Faculty of Information and Communication Technology located in Cyberjaya, Malaysia. UCI (Unity College International) was his previous Employer .He has done more than 80 Conference and journal Papers by now in his academic career. The majority of papers are around the fields of E- Commerce, Electronic Marketing, General Management and Human Resource Management.

Mr. Rashad Yazdanifard has been honored with several IEEE certificates for participation in many IEEE conferences. He also has been members of different examiner committee for several International conferences.

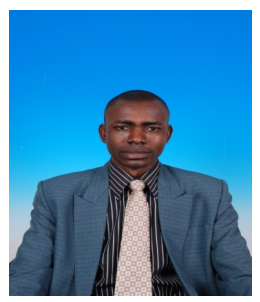

NNAMDI

OGBODOAKUM

(ENUGU/NIGERIA), Holds Higher National Diploma in Banking and Finance from Institute of Management and Technology Enugu Nigeria, Bachelor of Business Administration degree (B.B.A) in International Business from Limkokwing University of Creative Technology Malaysia. He is presently completing his MBA in Human Resource Management from the above University.

He has presented articles in local and International conferences.

Mr. Ogbodoakum, research interest include: Human Capital Management, Performance Improvement, Public Policy, Strategy and Emerging Markets. 